УДК 37.011

DOI: $10.15330 /$ esu. $16.79-84$
Вікторія Желанова,

доктор педагогічних наук, доцент,

Київський університет імені Бориса Грінченка (м. Київ, Україна)

Viktoriia Zhelanova,

Doctor of pedagogical sciences, Associate Professor,

Borys Grinchenko Kyiv University (Kyiv, Ukraine)

luckyeng@ukr.net

\title{
СУТНІСТЬ ТА СТРУКТУРА ГОТОВНОСТІ МАЙБУТНІХ ТЕХНІКІВ-ТЕХНОЛОГІВ ДО ПРОФЕСІЙНОӤ САМОРЕАЛІЗАЦӤ У КОНТЕКСТІ ТЕХНОЛОГІЙ ХАРЧУВАННЯ
}

\section{ESSENCE AND STRUCTURE OF READINESS OF FUTURE TECHNIQUES- TECHNOLOGIES SPECIALISTS FOR PROFESSIONAL SELF-REALIZATION IN FOOD TECHNOLOGIES}

\begin{abstract}
У статті представлено аналіз понять “готовність", "професійна готовність", "самореалізація", "професійна самореалізачія", як семантичних складників базового поняття дослідження. Розкрито сутність феномену готовність майбутніх техніківтехнологів з технології харчувания до професійної самореалізачії як складного інтегрованого особистісного утворення. шо містить систему професійних знань, умінь та навичок, а також якостей та станів, зоріснтованих на професійну самореалізацію особистості в професії як сукупності прочесів самопізнання, самоусвідомлення, саморегуляції, самотворення й самоконтролю. Представлено структуру готовності майбутніх техніків-технологів з технології харчування до професійної самореалізації, що містить мотиваційно-иіннісний компонент (сукупність чіннісного ставлення до майбутньої професійної діяльності техніків-технологів з технології харчування; бажання працювати техніком-технологом з технології харчування; мотиви, потреби, установки до самореалізачії у майбутній професіі); когнітивний компонент (знания нормативних документів державного й методичного рівня; знання технології виробництва харчової продукиіі; знания сучасних способів визначення якості сировини, напівфабрикатів, готових виробів; знання структури ринку та ринку постачальників продовольчої сировини; знання професійної термінології, канонів ділового спілкування; знання професійної етики та етикету); діяльнісний компонент (рефлексивні уміния (самоаналіз свосї професійної діяльності, усвідомлення власних ресурсів); уміння творчо реалізовувати теоретичні знання в нестандартпих ситуаціях професійної діяльності; володіния сучасними харчовими технологіями та вміння використовувати їх; уміння адаптується до нових професійних умов.
\end{abstract}

Ключові слова: готовність, професійна готовність, самореалізачія, професійна самореалізачія, готовність майбутніх техніків-технологів з технології харчування до професійної самореалізації.

The analysis of the concepts of "readiness", "professional readiness", "self-realization", "professional self-realization" as the semantic components of the basic concept of research is represented in the article. The essence of the phenomenon is the readiness of future technology technicians from the technology of food to professional self-realization as a complex integrated personal formation. which contains a system of professional knowledge, skills and qualities, as well as qualities and conditions, oriented to the professional self-realization of the individual in the profession as a set of processes of self-knowledge, self-awareness, self-regulation, self-control and self-control. The structure of preparedness of future technicians-technologists on the technology of nutrition to professional self-realization, which contains the motivational-value component (a set of value attitude to the future professional activity of technology technicians on the technology of mutrition, the desire to work as a technician-technologist on the technology of 
nutrition, motives, needs, installation of self-realization in the future profession); cognitive component (knowledge of normative documents of the state and methodological level; knowledges of food production technology; knowledge of modern methods for determining the quality of raw materials, semi-finished products, finished products; knowledge of the structure of the market and the market of suppliers of food raw materials; knowledge of professional terminology; canons of business communication; knowledge of professional ethics and etiquette); active component (reflexive skills (introspection of their professional activity, awareness of their own resources); ability to creatively implement theoretical knowledge in non-standard professional work situations; knowledge of modern food technologies and the ability to use them; skills adapt to new professional conditions.

Key words: readiness, professional readiness, self-realization, professional selfrealization, readiness of future technicians-technologists on the technology of nutrition.

Постановка проблеми. Стрімкі політичні, соціально-економічні, інноваційноосвітні трансформації в житті України, пов'язані з процесом інтеграції нашої держави до $\mathrm{EC}$, а також створення інформаційного системно-мережевого простору посилили високу конкуренцію на ринку праці серед техніків-технологів 3 технології харчування. До того ж збалансоване й якісне харчування $є$ запорукою здоров'я нації. 3 урахуванням цих суттєвих аспектів, метою сучасної професійної освіти $\epsilon$ підготовка компетентних конкурентоспроможних фахівців, які відповідають високим вимогам сьогодення та задовольняють потреби ринку праці. При цьому особливої ваги набуває проблема формування готовності майбутніх техніківтехнологів $з$ технології харчування до професійної самореалізації. Беручи до уваги усталені канони до побудови логіки наукового дослідження, є доцільним визначити сутність та структуру готовності майбутніх техніків-технологів 3 технології харчування до професійної самореалізації.

Аналіз останніх досліджень. Проблема професійної готовності досить широко й багатоаспектно представлена в психолого-педагогічній літературі. У загальнотеоретичному плані вона розроблена у працях А. Деркача, К. Дурай-Новакової, М. Дьяченка і Л. Кандибовича, А. Капської, А. Линенко, В. Моляка, О. Мороз, С. Сисоєвої, В. Сластьоніна та ін. Не дивлячись на деякі розбіжності в інтерпретації феномену “готовність" та його структури, він розглядається як первинна й фундаментальна умова успішного виконання будь-якої діяльності, як ступень мобілізації внутрішніх ресурсів людини в цілях найбільш ефективного розв'язання певних завдань. Низка досліджень присвячена аналізу більш вузьких проблем професійної готовності, а саме формування готовності до педагогічного аналізу (В. Чайка), виховної роботи (Г. Балахнічева, М. Гей, Г. Кіт), професійного спілкування (Л. Савенкова), освоєння передового педагогічного досвіду (О. Ярошенко), педагогічної взаємодії (М. Виєвська), реалізації принципів гуманної педагогіки (Л. Губарєва), роботи з сім'єю (С. Корнієнко, К. Мукашева, О. Семиног), інноваційної (К. Макагон) та дослідницької (В. Борисов) педагогічної діяльності, готовності директора школи до управління якістю освіти (Б. Жебровський); виховання морально-психологічної готовності до професійної діяльності (Л. Кондрашова) та шляхів іiі формування (О. Івлієва). Проблему професійної підготовки майбутніх фахівців харчової галузі представлено у студіях І. Дрозіч, Л. Козловської, Т. Сергєєва, І. Філімонової. Питання формування готовності до інноваційної діяльності майбутніх технологів у коледжах аграрного профілю висвітлено у дослідженні В. Кобзар.

Отже аналіз праць зазначених науковців дає підстави стверджувати, що проблема формування готовності до професійної самореалізації майбутніх техніків- 
технологів з технології харчування порушується в них лише аспектно й не була предметом спеціального дослідження. До того ж соціально-економічні зміни, що відбуваються у нашій країні, призводять до зростання потреби держави у висококваліфікованих фахівцях 3 технології харчування, a реальний рівень підготовки названих спеціалістів не завжди відповідає сучасним вимогам. 3 огляду цих позицій, вивчення та вирішення даної проблеми $є$ актуальним питанням сучасної професійної освіти.

Ціль статті - визначити сутність та структуру готовності майбутніх техніківтехнологів до професійної самореалізації.

Виклад основного матеріалу. У психолого-педагогічній теорії існують різні підходи до визначання змісту, а також структурних компонентів готовності особистості. Поняття “готовність" розглядається як новоутворення (Л. Виготський, Д. Ельконін); як психічний стан особистості (А. Капська, О. Мороз, В. Сластьонін); як установка (Д. Узнадзе); як виражений часовий ситуативний стан (Г. Рудик); як стан мобілізації всіх психофізичних систем людини (Ф. Генов); як наявність здібностей (Б. Ананьєв, С. Рубінштейн); як якість особистості (К. Платонов); як “ансамбль", синтез властивостей особистості (В. Крутецький); як складна інтегрована якість особистості (В. Ширінський); як єдність поведінкового, когнітивного й емоційного компонентів (Д. Катц, Д. Креч, М. Кровгільд); як єдність спонукального (мотиваційного) і виконавчого (процесуального) компонентів (В. Селіванов); як сукупність мотиваційних, пізнавальних, емоційних, вольових якостей особистості (3. Козлов, Ю. Кулюткін).

Науковці також виокремлюють різні види готовності, а саме: психологічну, науково-теоретичну, практичну, психофізіологічну, фізичну (В. Сластьонін); тривалу та короткочасну (Н. Левітов, А. Пуні, М. Дьяченко Л. Кандибович ).

Отже маємо констатувати, що надаючи різні тлумачення поняттю “готовність", дослідники погоджуються в тому, що готовність є інтегрованою характеристикою особистості, що містить дві складові: теоретичну та практичну.

Далі репрезентуємо більш грунтовні наукові позиції щодо трактування феномену професійної готовності. Згідно з підходом К. Дурай-Новакової, професійна готовність $є$ системою інтегральних якостей, властивостей, знань, навичок особистості [4]. За визначенням В. Сластьоніна, професійна готовність $є$ системною якістю, що містить, окрім сформованої професійної значущості, систему знань, умінь, навичок, сформованість професійно зумовлених якостей особистості, педагогічних здібностей, мотивів, інтересів, основ педагогічної майстерності [9]. І. Дичківська визначає професійну готовність як особливий особистісний стан, який передбачає наявність у педагога мотиваційно-ціннісного ставлення до професійної діяльності, володіння ефективними способами i засобами досягнення педагогічних цілей, здатності до творчості та рефлексії [3].

При цьому є доцільним звернути увагу на підхід М. Дьяченка та Л. Кандибовича, які розглядають психологічну готовність як істотну передумову цілеспрямованої діяльності, як стійку характеристику особистості, що містить позитивне відношення до професійної діяльності; мотивацію, здібності, темперамент, риси характеру, адекватні вимогам професії, а також необхідні знання, вміння, навички, стійкі професійно важливі особливості сприйняття, мислення, емоційних та вольових процесів. Короткочасну готовність, або стан готовності науковці розглядають як "кожний раз створюване функціональне вістря довготривалої готовності, що підвищує іiі дієвість” [5, с. 278]. 
Отже, грунтуючись на поданих вище теоретичних положеннях, маємо відзначити, що будучи складною синтезованою якістю, професійна готовність техніківтехнологів з технології харчування інтегрує психологічну, теоретичну, практичну готовність. При цьому психологічна готовність відбиває мотиваційно-цінністний; теоретична - когнітивний; практична - діяльнісний компоненти професійної готовності. При цьому структуру професійної готовності складають дві функціонально взаємопов'язані підсистеми, а саме:

1) тривала готовність як стійкий комплекс професійно важливих знань, умінь, якостей і властивостей особистості, що необхідні для результативної професійної діяльності;

2) ситуативна готовність як психічний стан перебування “внутрішнього настрою” на подолання професійних труднощів, прагнення проявити творчість в розв'язанні професійних проблем.

Ураховуючи, що аспектом, 3 яким пов'язана професійна готовність техніківтехнологів з технології харчування у межах представленого дослідження $є$ готовність до професійної самореалізації, зосередимось на з'ясуванні ії сутності.

Відоме трактування самореалізації як творчого ставлення індивіда до самого себе, створення ним самого себе в процесі активного впливу на зовнішній i внутрішній світ з метою їхнього перетворення [8].

Більш узагальнене тлумачення спостерігаємо у Л. Коростильової, яка визначає самореалізацію як процес здійснення самого себе в житті та в повсякденній діяльності, пошук та ствердження свого особливого шляху в цьому світі, своїх цінностей та сенсу існування в кожний момент часу. Вона можлива тільки за умови сильного збуджуючого мотиву до особистісного росту. Процес самореалізації спрямований зсередини у зовнішню реальність. Для розуміння феномену самореалізації науковець виділяє ряд істотних аспектів: самоактуалізацію, вираз істинної природи людини, самовираження, самовдосконалення, адаптацію, моральність, індивідуалізацію, мотивуючу силу, свободу, щастя та властивості особистості [6].

Щодо професійної самореалізації - вона розуміється як процес підвищення рівня власної професійної компетентності і розвитку професійно значущих якостей відповідно до зовнішніх соціальних вимог, умов професійної діяльності, особистої програми розвитку (К. Альбуханова-Славська) [1]; процес і результат цілеспрямованого самотворення, яке досягається завдяки самоосвіті та самовихованню i забезпечує постійне підвищення професійної майстерності (М. Ксьонзенко) [7];

В. Гриньова трактує професійну самореалізацію як свідомий цілеспрямований процес підвищення рівня власної професійної компетентності, розвиток професійно значущих властивостей, ціннісних орієнтацій відповідно до зовнішніх соціальних вимог, умов професійної діяльності й особистої програми розвитку “Я-концепції, що передбачає сформованість досконалого рівня педагогічної культури [2].

Л. Сущенко визначає "професійну самореалізацію" як внутрішній процес якісних самозмін, який відбувається за рахунок усвідомлення фахівцем необхідності самовдосконалення, грамотного самоаналізу, власних роздумів і порівнянь своєї діяльності 3 діяльністю інших фахівців, яких визнано зразковими; мотивованого, цілеспрямованого і добре організованого саморуху до найкращого в собі [10].

Отже, базуючись на окреслених позиціях щодо трактування професійної реалізаціі, маємо констатувати, що вона пов'язана 3 процесами самопізнання, самоусвідомлення, саморегуляції, самотворення й самоконтролю. 
Відтак логіка попереднього розгляду феноменів готовності, професійної готовності, самореалізації та професійної самореалізації дають підстави визначити професійну готовність техніків-технологів з технології харчування до професійной реалізації як інтегроване особистісне утворення, що містить систему професійних знань, умінь та навичок, а також якостей та станів, зоріснтованих на професійну самореалізацію в професії як сукупності процесів самопізнання, самоусвідомлення, саморегуляції, самотворення й самоконтролю.

В структурі зазначеного феномену виокремлюємо мотиваційно-ціннісний, когнітивний, діяльнісний компоненти.

1. Мотиваційно-цуіннісний компонент містить такі складники, як-от:

- ціннісне ставлення до майбутньої професійної діяльності техніків-технологів 3 технології харчування;

- бажання працювати техніком-технологом з технології харчування;

- мотиви (соціальні, пізнавальні, професійні), потреби, установки до самореалізації у майбутній професії.

2. Когнітивний компонент представлений сукупністю знань, а саме:

- знання нормативних документів державного й методичного рівня;

- знання технології виробництва харчової продукції;

- знання сучасних способів визначення якості сировини, напівфабрикатів, готових виробів;

- знання структури ринку та ринку постачальників продовольчої сировини;

- знання професійної термінології, канонів ділового спілкування;

- знання професійної етики та етикету.

3. Діяльнісний компонент містить систему умінь:

- рефлексивні уміння (самоаналіз своєї професійної діяльності, усвідомлення власних ресурсів);

- уміння творчо реалізовувати теоретичні знання в нестандартних ситуаціях професійної діяльності;

- володіння сучасними харчовими технологіями та вміє їх використовувати;

- уміння адаптується до нових професійних умов.

Висновки. Аналіз варіантів наукової інтерпретації поняття "готовність" як новоутворення; як психічного стану особистості; як установки; як стану мобілізації всіх психофізичних систем людини; як наявності певних здібностей; як синтезу властивостей особистості; як складної інтегрованої якості особистості; як сукупності мотиваційних, пізнавальних, емоційних, вольових якостей особистості, а також трактування професійної самореалізації як процесу підвищення рівня власної професійної компетентності і розвитку професійно значущих якостей, дав підстави визначити професійну готовність майбутніх техніків-технологів 3 технології харчування як інтегроване особистісне утворення, що містить систему професійних знань, умінь та навичок, а також якостей та станів, зорієнтованих на професійну самореалізацію в професії як сукупності процесів самопізнання, самоусвідомлення, саморегуляції, самотворення й самоконтролю. У структурі зазначеного феномену виокремлено мотиваційно-ціннісний, когнітивний, діяльнісний компоненти.

Перспективним напрямом подальших наукових розвідок вважаємо аспект, пов'язаний $з$ розробкою методичного супроводу процесу формування готовності майбутніх техніків-технологів з технології харчування до професійної самореалізації. 


\section{Література}

1. Абульханова К. А, Березина Т. Н. Время личности и время жизни / К. А. Абульханова, Т. Н. Березина. - СПб.: Алетейя, 2001. - 304 с.

2. Гриньова В. М. Формування педагогічної культури майбутнього вчителя : Теоретичний та методичний аспекти / В. М. Гриньова. - Х. : Основа, 1998. - 299 с.

3. Дичківська I. М. Інноваційні педагогічні технології : навч. посіб. / I. М. Дичківська. К. : “Академвидав, 2004. - 352 с.

4. Дурай-Новакова К. М. Формирование профессиональной готовности студентов к педагогической деятельности : дис. ... д-ра пед. наук : 13.00 .08 / Дурай-Новакова Кристина Мечиславовна. - М., 1983. - 356 с.

5. Дьяченко М. И. Психология высшей школы. / М.И. Дьяченко, Л.А. Кандыбович - Минск, изд-во БГУ. - 1978. - 279

6. Коростылева Л.А. Психология самореализации личности: Основные сферы жизнедеятельности: дисс...д- ра психол.наук. - СПб, 2001. - 398 с.

7. Ксьонзенко М.А. Самовиховання вчителя як невід'ємна частина його професійного самовдосконалення [Текст] / М. А. Ксьонзенко // Наукова скарбниця Донеччини. - 2011. №1(8). - С. 84-87.

8. Психологічна енциклопедія [Текст] / [автор-упорядник Степанов О. М.]. - Київ : Академвидав, 2006. $-424 \mathrm{c}$.

9. Сластенин В. А. Педагогика [Текст] : учебное пособие для студ. высш. пед. учеб. заведений / В. А. Сластенин, И. Ф. Исаев, Е.Н. Шиянов ; под ред. В. А. Сластенина. - Москва : Издательский центр “Академия”, 2002. - 576 с.

10. Сущенко Л.О. Стимулювання професійного самовдосконалення вчителів по чаткових класів у системі післядипломної освіти : автореф. дис. ... канд. пед. наук : 2013 р., Вип. 28 (81) 551 13.00.04 / Лариса Олександрівна Сущенко ; Університет менеджменту АПН України. - Київ, 2009. $-22 \mathrm{c}$

\section{References}

1. Abul'hanova K. A, Berezina T. N. Vremya lichnosti i vremya zhizni / K. A. Abul'hanova, T. N. Berezina.- SPb.: Aletejya, 2001. - 304 s.

2. Grin'ova V. M. Formuvannya pedagogichnoï kul'turi majbutn'ogo vchitelya : Teoretichnij ta metodichnij aspekti / V. M. Grin'ova. - H. : Osnova, 1998. - 299 s.

3. Dychkivska I. M. Innovatsiini pedahohichni tekhnolohii : navch. posib. / I. M. Dychkivska. - K. : "Akademvydav, 2004. - $352 \mathrm{~s}$.

4. Duraj-Novakova K. M. Formirovanie professional'noj gotovnosti studentov k pedagogicheskoj deyatel'nosti : dis. ... d-ra ped. nauk : 13.00.08 / Duraj-Novakova Kristina Mechislavovna. - M., 1983. $-356 \mathrm{~s}$.

5. D'yachenko M. I. Psihologiya vysshej shkoly. / M.I. D'yachenko, L.A. Kandybovich - Minsk, izdvo BGU. - 1978. - 279

6. Korostyleva L.A. Psihologiya samorealizacii lichnosti: Osnovnye sfery zhiznedeyatel'nosti: diss...dra psihol.nauk. $-\mathrm{SPb}, 2001$. $-398 \mathrm{~s}$.

7. Ksonzenko M. A. Samovykhovannia vchytelia yak nevidiemna chastyna yoho profesiinoho samovdoskonalennia [Tekst] / M. A. Ksonzenko // Naukova skarbnytsia Donechchyny. 2011. №1(8). S. 84-87.

8. Psykholohichna entsyklopediia [Tekst] / [avtor-uporiadnyk Stepanov O. M.]. - Kyiv : Akademvydav, 2006. $-424 \mathrm{~s}$.

9. Slastenyn V. A. Pedahohyka [Tekst] : uchebnoe posobye dlia stud. vyissh. ped. ucheb. zavedenyi / V. A. Slastenyn, Y. F. Ysaev, E. N. Shyianov; pod red. V. A. Slastenyna. - Moskva : Yzdatelskyi tsentr "Akademyia", 2002. - $576 \mathrm{~s}$.

10. Sushchenko L.O. Stymuliuvannia profesiinoho samovdoskonalennia vchyteliv po chatkovykh klasiv u systemi pisliadyplomnoi osvity : avtoref. dys. ... kand. ped. nauk : 2013 r., Vyp. 28 (81) 551 13.00.04 / Larysa Oleksandrivna Sushchenko ; Universytet menedzhmentu APN Ukrainy. - Kyiv, 2009. $-22 \mathrm{~s}$ 